Vol. 3, No. 06 Nov-Dec; 2021 Page. No. 01-28

To cite this article: Niu, Lung-Kuang (2021). TO SHARE THE ONLINE SPIRITUAL OR RELIGIOUS KNOWLEDGE: INTEGRATING THE SELF-CONGRUITY AND SOCIAL CAPITAL THEORIES, International Journal of Research in Commerce and Management Studies (IJRCMS) 3 (6): 01-28

\title{
TO SHARE THE ONLINE SPIRITUAL OR RELIGIOUS KNOWLEDGE: INTEGRATING THE SELF-CONGRUITY AND SOCIAL CAPITAL THEORIES
}

\author{
Niu, Lung-Kuang \\ Fo Guang University \\ DOI: http://dx.doi.org/10.38193/IJRCMS.2021.3601
}

\begin{abstract}
Background: The purpose of this study is to analyze the relationship between actual self-congruity, ideal self-congruity, trust, the norm of reciprocity, identification, extrinsic religiosity, intrinsic religiosity, spirituality, and shared knowledge of the online spiritual or religious messages from the perspective of self-congruity and social capital theories.

Materials and Methods: The study selected 119 (82 females and 37 males) interviewees. Researchers used partial least squares (PLS) regression and confirmatory factor analysis (CFA) to measure the model and test the hypothesis.

Results: The study showed that actual self-congruity is positively related to trust, the norm of reciprocity, identification, and extrinsic religiosity-ideal self-congruity is positively related to intrinsic religiosity and spirituality. Identification, extrinsic religiosity, and spirituality are positively related to online shared knowledge.

Conclusion: Cognitive dimension of social capital is related to ideal self-congruity. Relational and structural dimensions of social capital are related to actual self-congruity. Ideal self-congruity derives from self-identity, and actual self-congruity derives from self-consistency. Self-identity is associated with intrinsic religiosity and spirituality. Self-consistency is associated with trust, the norm of reciprocity, identification, and extrinsic religiosity. Self-identity and self-consistency are positively related to online shared knowledge.
\end{abstract}

KEYWORDS: Self-congruity, Social Capital Theory, religiosity, spirituality, online shared knowledge

\section{INTRODUCTION}

It was a current phenomenon that online spiritual or religious activity incorporated purchasing online spiritual or religious brands to draw fans' or believers' attention in an online context (Sardana et al., 2018). Individuals put the spiritual or religious association in competition and secularization in the online spiritual or religious context. An online spiritual or religious brand's dilemma between online 
spiritual or religious marketing practices and devotional activities for spiritual or religious organizations might influence believers' spiritual or religious consumer activities preference (Stolz \& Usunier, 2019).

Typically, bloggers or online celebrities influence readers or fans. Their online personae might even become well-known. As a result, bloggers or online celebrities had a fascination authority on readers or fans (Cocker \& Cronin, 2017). Religious celebrities would elicit positive emotional responses from the readers or fans in Indonesia (Hatherell \& Welsh, 2017).

The user platform could maintain in-progress diaries to record and share their daily thoughts and experiences, becoming individual medium platforms for self-narratives (Calzati \& Simanowski, 2018). Uzuno glu \& Kip (2014) indicated that brand communication highlighted the importance of the flow of the brand messages in the digital environment. Peer communication influenced both the opinion leaders and their followers that had a growing power to constitute the function of brands.

Brand communication was a type of marketing communication. Most bloggers or online celebrities could manage their brands through daily activity on their blogs or online platforms. Celebrities' or bloggers' distinctive impression management is achieved and maintained through in-depth narratives and personal descriptions of everyday activities and represented self-images (Magdalena, 2019).

According to social capital theory, there are three dimensions of social capital: relational dimension, structural dimension, and cognitive dimension. At the group level, it reflects the affective nature and relationship quality (RQ). While at the individual level, it demonstrates an individual's action and access to a network resource (Huang et al., 2009). Trust and commitment will impact the RQ between celebrities and believers based on word-of-mouth (WOM) (Akrout \& Nagy, 2018). Is RQ related to trust, commitment or other variables?

This paper combined the social capital theory, self-image, and other variables to analyze the effectiveness of spiritual or religious messages. Self-image was the critical approach to influence user opinion and managing electronic word-of-mouth (eWOM) communication in the user-generated content (UGC), such as YouTube Live or Facebook direct broadcast.

The research objectives are as follows: (1) to understand what self-image factors impact social capital factors? (2) to understand how social capital factors will impact online practitioners' spiritual and religious knowledge sharing? The researcher reviews the literature to conclude, praise and critique some past studies and research. 


\section{LITERATURE REVIEW}

\subsection{Self-congruity}

Self-congruity was synonymous with self-image congruity and image-congruity within consumer behavior literature (Sirgy et al., 1997). Self-concept was related to an individual's perception of selfregarding. There were four types of self-concept: actual self-congruity, ideal self-congruity, actual social congruity and ideal social congruity (Sirgy, 1985).

Self-congruity is achieved through the interaction between self-concept and the product-user image. The product-user image could be a performance of value-expressive or symbolic options (Sirgy et al., 1997). According to Sirgy (2018), self-congruity will impact purchase motivation by satisfying selfconsistency, self-esteem, social consistency, and social approval needs.

Hu et al. (2017) indicated that broadcaster identification and group identification drive live streaming platform viewing behavior. Parasocial interaction and self-congruity increase continuance intention. The result will increase broadcaster identification to audiences. Co-experience among audiences will improve group identification. The streaming genres moderate the effects of identifications on continuance intention.

Self-consistency and self-esteem theories make a case for the connection of actual self-congruity, ideal self-congruity and purchase motivation. Sirgy (1985) tested the effects of actual self-congruity and ideal self-congruity on purchase motivation and located an area of unit positive influence with the purchase motivation. The results of this study demonstratively support this relationship.

Vigolo \& Ugolini (2016) indicated that the actual self-congruity and ideal self-congruity refer to somebody's perspective towards or appraise a brand and stem from the practical value and repurchase intention. Ideal self-congruity was a stronger predictor of repurchase intentions than actual selfcongruity.

The association of the self and the brand is influenced by self-congruity (Sirgy et al., 1991). Customers typically select products or brands that are self-relevant (Johnson et al., 2011). Self-congruity manifested in self-esteem and self-consistency. Individuals choose to behave in line with one's selfview and ensure the worth of their being (Vigolo \& Ugolini, 2016). Moreover, ideal self-congruity stems from self-esteem or self-extension. Individuals wish to realize or replicate their ideal self and extend the real or true self (Sirgy, 1985).

Ego-identity was synonymous with Self-identity that had outlined as a theory of self. The self-identity 
exploration sought information and tested hypotheses concerning self-speculation and sought information associated with the self (Dunkel \& Lavoie, 2005).

Choi \& Rifon (2012) indicated that celebrities could promote a product. Celebrity endorsers were valuable assets to advertisers. The celebrity endorser effectiveness was matched between endorser and product as well as attained the congruence between consumers' perception of self-concept and the celebrity's personality characteristics. Consumers' self-concept would influence purchase decisions. The ideal self-congruity (congruence between consumers' ideal self-congruity and celebrity image) was an influential variable to draw in fans.

Self-congruity contributes to the perception of the brand's practical attributes and improves evaluations of concrete brands. Individuals would order self-referential information to involve in a brand and have expressed an intention to process useful related information (Kim, 2015).

Kang et al. (2015) developed an association between image congruity (self-congruity and functional congruity) and brand loyalty components (cognitive, affective and conative loyalty). The researchers found that self-congruity influenced each cognitive and emotional loyalty within the central route of persuasion. Functional congruity influenced cognitive loyalty within the peripheral way of communication.

Motivated by this logic, this study argues that spiritual celebrities will manage one's brand most simply. The celebrity's appearance reflects the believer's actual or ideal self. The celebrity's image congruent with believers' actual self-image satisfies believers' self-consistency. Additionally, if the celebrity's image reflects believers' ideal self-image, believers feel nearer to a perfect self, which might help their self-identity.

The effect of self-congruity indicates that the image of the celebrities influences a consumer. Selfcongruity matched the consumers' self-concept and a given embodiment of a product, brand, or fame. Customers might cause the brands' trust from images compatible with their perception of ideal selfcongruity, brand attractiveness, and brand distinctiveness, which indirectly influences brand identification, not affected by the perception of actual self-congruity (Azizi \& Daei, 2014).

Nolan and Harold (2010) used the image congruity theory to test the decision-making process. Their study researched workers from various jobs/organizations who read a series of job advertisements that presented unique organizational personalities. Then, they rated the extent to which these personalities matched their self-concept perceptions and reported evaluations of organizational attractiveness. The research results indicated that prospective job seekers are attracted to organizations with characters 
they perceive as similar to their actual and ideal self-concepts. Actual self-congruity exerted a more significant influence on organizational attractiveness than ideal self-congruity. However, actual and ideal self-congruity explained substantial organizational attractiveness.

According to $\mathrm{Hu}$ et al. (2017), live video streaming became economic globalization and social phenomenon. Several streaming platforms, such as Twitter and YouTube Live, continue growing in popularity. The researchers explained the dual identification framework: identifications with streaming broadcasters and audience groups are positively related to the audience's behavioral intention.

Shih et al. (2013) indicated that eWOM communication is transmitted within the commercial market and changes consumer attitudes and behaviors. Indeed, eWOM communication was not evaluated solely as a data exchange but conjointly as a social exchange. The dedication-based relative influence was more critical than the constraint-based relative effect. Moreover, emotional attitudes had a more significant impact on eWOM communication intention than cognitive perspectives did. And, the dedication-based relational influence was more potent than informational influence in driving online referral behaviors.

According to Wang et al. (2015), readers perceiving self-congruity with beauty bloggers raise the bloggers' informational influence, mediated by blogger-reader relationship quality and functional congruity. Compared to actual self-congruity, ideal self-congruity was a more powerful triggering force of functional congruity. Actual self-congruity was a more powerful triggering force of informational influence than ideal self-congruity.

Self-congruity theory can explain the relationship between bloggers and readers. But the idea was not enough to justify the information exchange or knowledge sharing between sender and receiver. So, we need to re-praise and re-critique self-congruity theory to review the spiritual or religious knowledge sharing phenomenon.

\subsection{Social Capital Theory}

The concept of social capital is focused on community studies initially. From the general point of view, the idea of social capital is similar to networks of a solid personal relationship. It can give the basis for trust, cooperation, and collective action in communities (Jacobs, 1965).

According to Putnam (1995), the central proposition of social capital theory is that networks of relationships constitute a valuable resource for social affairs. The social members with the collectively-owned capital have credential capital to enable them to credit in the various senses of the 
word (Bourdieu, 1986). The three clusters of social capital are the relational, the structural, and the cognitive dimensions.

The distinction between structural and relational dimensions of social capital is clear. The structural dimension of social capital concerns the properties of the social system and the network of relations as a whole. The relational dimension is involved with the kind of personal relationship and people interacting with each other (Granovetter, 1992). The third dimension of social capital is the cognitive dimension and refers to resources providing shared representations, interpretations, and systems of meaning among parties (Cicourel, 1973).

All the forms of social capital have two characteristics in common. The first is that social capital constitutes some aspect of the social structure. Social capital is a social-structural resource and relates between persons and among persons (Burt, 1992). The second is that social capital facilitates the individuals' actions within the system (Coleman, 1990). Social capital also makes possible the achievement of a goal without needing an extra cost (Nahapiet \& Ghoshal, 1998).

Social capital can increase the efficiency of action and information diffusion (Burt, 1992). The structure of social capital is relatively restricted, and these boundaries typically come from some external physical or social basis for grouping. Some objects of research by the social capital theory are focused on geographic community (Jacobs, 1965), the family (Coleman, 1988), religion (Coleman, 1990), class (Bourdieu, 1977), or virtual communities (Chiu et al., 2006). This research is focused on the virtual community to understand online shared knowledge.

\subsection{Relational dimension of social capital}

The relational dimension of social capital improves the personal relationships that people have developed through a history of interactions (Granovetter, 1992). The relational dimension of social capital also improves RQ and overall associate assessment of the strength of the bipolar relationship between sellers and buyers. The product meets the wants and expectations of the buyers. According to Sarmiento et al. (2018), trust, satisfaction and commitment identify the main dimensions that form the RQ.

Smith (1998) used similarity-attraction theory to determine the relationship between work attitudes, sex, life stage, and personality. The similarity in buyer-seller had different effects in facilitating open communication, relationship investment, and relationalism. RQ is among the relative constructs for being a mediator wherever researchers have conceptualized relationship management results. Thus, RQ could arise once believers understand the product as near one's actual self or ideal self (Gan \& Chen, 2017). 
According to Gefen et al. (2003), trust was specific beliefs dealing primarily with integrity, benevolence, and ability. Nahapiet and Ghoshal (1998) indicated that trust is a significant antecedent of intellectual capital exchange. Nonaka (1994) noted that inter-personal trust is essential in teams and organizations for creating an atmosphere for knowledge sharing. When trust exists between the parties, the group members are more willing to engage in cooperation interaction. So, trust is an essential factor of involuntary behavior such as knowledge sharing in a virtual community.

Seehusen et al. (2013) indicated that the need to belong is positively related to nostalgia proneness and neuroticism. Belongingness orientation predicted increased nostalgia proneness. Belongingness deficits would increase the sense of nostalgia. When the belongingness orientation is controlled, the positive correlation between nostalgia and neuroticism disappears.

The norm of reciprocity refers to knowledge exchange in mutual relationships and is recognized as fair by the parties. Thibaut \& Kelly (1959) indicated that participants in virtual communities expect mutual reciprocity to adjust their expense and time to share knowledge. Blau (1964) pointed that reciprocity implies the contingent on rewarding actions from others, and the reaction will be forthcoming.

According to Bagozzi and Dholakia (2002), identification was the same as one's conception of selfregarding the defining features of self-inclusive social category in the virtual community. Nahapiet and Ghoshal (1998) indicated that identification is individuals viewing themselves as group members. Ellemers et al. (1999) noted that emotional identification refers to an individual's sense of belonging and positive feeling toward a virtual community.

\subsection{Structural dimension of social capital}

Online practitioners are not just seeking information, knowledge, or solving problems when visiting virtual communities; they also find a place to meet other people and seek support, friendship, and a sense of belonging (Andrews, 2002; Zhang \& Hiltz, 2003). Religiosity is some belonging for online practitioners. What was religiosity? Allport and Ross (1967) indicated two fundamental dimensions of religiosity: intrinsic religiosity and extrinsic religiosity. They were different kinds of values.

Rokeach (1973) suggested that values could divide two types of matters. The first type was terminal values that were also called personal values or social values. Individuals wanted to achieve the ultimate value of their entire lives. The second type was instrumental values that were also called capable values or moral values. Individuals have used these values as behavioral expressions (Hofstede \& Bond, 1984). 
Extrinsic religiosity was a self-serving and practical outlook that provided believers a comfortable feeling of salvation. It meant reaching some security, solace, status, sociability, distraction, and selfjustification. Extrinsic values were always instrumental and utilitarian (Allport \& Ross, 1967). Extrinsic religiosity could enhance the self-serving and follow the instrumental approach to suit oneself.

It is a structural dimension of social capital for extrinsic religiosity because online spiritual or religious practitioners are seeking support, making friends on the Internet. They want to strengthen their social capital on the Internet. They also meet other believers on the online interactional activities. The online practitioners with extrinsic religiosity try to make their structural capital more and strong.

\subsection{Cognitive dimension of social capital}

The cognitive dimension of social capital represents a meaningful set of assets and refers to the resources providing shared representation, interpretation, and system of meaning among parties (Cicourel, 1973). For online spirituality or religiosity, there is some cognitive dimension between online spiritual or religious practitioners. Intrinsic religiosity and spirituality are some kinds of the cognitive dimension of social capital.

Trimble (1997) claimed that social desirability shaped intrinsic religiosity, not extrinsic religiosity. Social desirability was some kind of social value. It was related to intrinsic religiosity in a given situation. Furthermore, it was not associated with extrinsic religiosity. Intrinsic religiosity was related to ultimate value, social desirability, mental health, altruism, or religious commitment. Extrinsic religiosity was related to instrumental matters, social undesirability, prejudice, or non-marital sex.

Intrinsic religiosity internalized the whole principle of faith without reservation. Believers with intrinsic religiosity were living one's religion. It was not with a self-serving bias to attend the church (Allport \& Ross, 1967). It was connected to the entire creed of faith and participated in church or temple activities. Thus, intrinsic religiosity was a meaning-endowing framework to seek the deeper values of the faith.

Spirituality comes from the Latin word "Spiritus", and meaning is "breath of life". It represents a transcendent dimension of being and experiencing awareness. Spirituality also refers to an identifiable value to self, others, nature, and life (Elkins et al., 1988). Spirituality also is called the "Holy Spirit of God." (Schneiders, 1989).

The meaning of religiosity is the same with such words: religiousness, orthodoxy, faith, religious belief, piousness, devotion and holiness. It means that religiosity studies have different religious 
dimensions, not equivalent to one religious extent (Holdcroft, 2006; Lewis, 1978).

The separate assessment of general Spirituality/religiosity ( $\mathrm{SpR}$ ) and religious coping had proved useful: Among members of Christian churches who envisioned severe adverse life events. General SpR was essential to one's life and viewed as a stable disposition that might constitute a resource in coping with various stresses or diseases. Religious coping was an active religious faith and the behavioral reaction of believers within a situational crisis. Faith was the critical resource of many patients with cancer (Sherman \& Simonton, 2001). Pargament et al. (1990) found that religious coping measures exhibited greater predictive power than dispositional religious variables. Coping was usually viewed as a process in which individuals tried to understand their life and deal with significant personal or situational demands (Lazarus \& Folkman, 1984).

Beck (1986) indicated that spirituality is an inner state of being and the ultimate force within a person. Spirituality is a fundamental dimension of the human being's lived experience (Schneiders, 1989). Reich et al. (1999) noted that spirituality is a sharing of joy and sorrow. It was the deep connections between human beings or them and nature. It was a connection between human beings and the higher being.

According to Clark (1958), spirituality was the person's inner experience of the sense of Beyond (McCormick, 1994). The spiritual dimension included specific values, attitudes, perspectives, beliefs, emotions, and was a human phenomenon and existed in all persons. Spirituality was also not affiliated with traditional religion. Spirituality synthesized the nine components: transcendent dimension, meaning and purpose in life, mission in life, the sacredness of life, material values, altruism, idealism, the tragical awareness, and fruits of spirituality (Elkins et al., 1988).

Pargament (1999) indicated two dilemmas of the spirituality's construct: ungrounded study and polarization between spirituality and religiosity. The first dilemma was the study of religiosity and spirituality to be ungrounded. First, even though the two terms contrasted with each other in the literature, the distinction between them was not clear. Second, individuals were to be spiritual and religious. The second dilemma was the polarization between spirituality and religiosity, the polarization between institutional and individual, and the good and evil. It also makes for the polarization between intrinsic religiosity and extrinsic religiosity. These two concepts were no distinction from each other.

\subsection{Shared knowledge}

Sun et al. (2006) indicated that innovativeness, Internet usage, and Internet social connection significantly impacted online word-of-mouth. Norman and Russell (2006) suggested that pass-along 
was a kind of eWOM communication. Consumers' pass-along messages were desire for social interaction, desired economic incentives, concern with other consumers, and the potential to enhance their self-worth (Hennig-Thurau et al., 2004).

An essential function of social capital was the ability to pool, create, and disseminate knowledge. Organizational studies showed that sources of social capital encourage a person to share one's knowledge and develop new intellectual capital to build competitive organizational advantages (Adler \& Kwon, 2002).

Tsai and Ghoshal (1998) indicated that a shared vision is setting the collective goal and aspirations of the members of an organization. A shared vision was viewed as a bonding mechanism to integrate and combine resources. The group members were sharing and exchanging an idea that would become partners with other group members.

\subsection{Merged theoretical framework}

The research combined the self-congruity theory and social capital theory as socio-psychological theory. The researcher combined the variables: actual self-congruity (ASC), ideal self-congruity (ISC), trust (Tru), the norm of reciprocity (Rec), identification (Ide), extrinsic religiosity (ER), intrinsic religiosity (IR), spirituality (Spi), and online shared knowledge (OSK) to constitute the model. The united theoretical framework broadened by incorporating self-congruity theory and social capital theory for online network contexts. The researcher wants to merge the above two views and has a more considerable explanatory power. Figure 1 shows the graphical illustration of the unified theoretical model.

Figure 1. The proposed research model

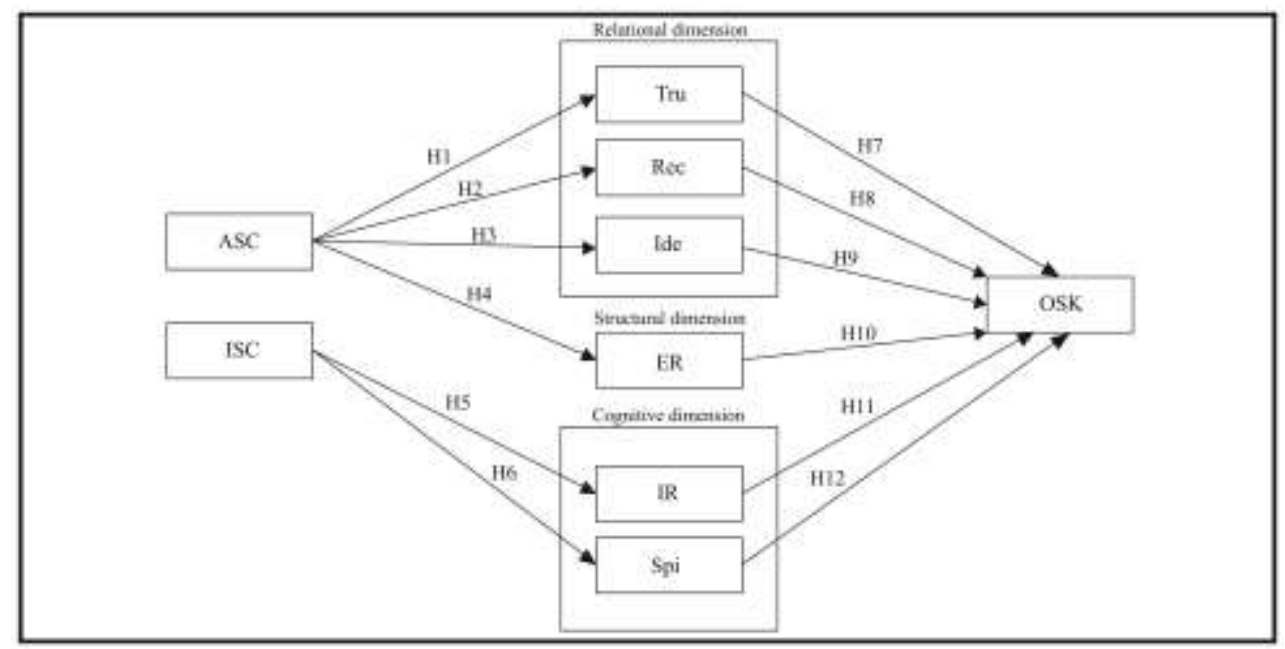




\section{Hypothesized relationships}

According to Carrim (2018), actual self-congruity mediates religiosity and store loyalty. Actual selfcongruity is an alternative approach to developing store loyalty where the market is highly religious. Meanwhile, religiosity is a stable and reliable predictor to impact loyalty intentions. According to Bukhari and Isa (2019), the proposed Islamic branding model applied to local and multinational brands in Muslim majority and minority markets. Religiosity, Islamic brand knowledge and Islamic corporate social responsibility were the antecedents of Islamic branding. The brands attracted Muslim consumers that portrayed congruity with their religious values.

According to Biswas et al. (2009), source credibility has divided into three categories: attractiveness, trustworthiness, and expertise. Self-congruity significantly affects source credibility that comprising of attractiveness, trustworthiness, and expertise. Self-congruity also can influence consumer attitudes, loyalty, and behavioral intentions. The actual self-congruity is the real image of the source and consumers' perceived image. Hence, hypothesis one (H1) is that ASC is positively related to Tru.

Self-congruity also has been found to influence consumer attitudes, loyalty, and behavioral intentions (Biswas et al., 2009). Some online spiritual or religious practitioners will have loyalty with the members and believes in each other. Hence, hypothesis two (H2) is that ASC is positively related to Rec.

The actual self-congruity is related to self-consistency. The self must demand the self-image congruence with the products or idols (Sirgy, 2018). It is not the ideal self-congruity to build the actual image of the products. So, the actual self-congruity is the critical variable to consumers' identification. Hence, hypothesis three $(\mathrm{H} 3)$ is that ASC is positively related to the Ide.

According to Ahmed (2015), religiosity influenced specific consumption. When someone feels the product will improve their self-image, they will associate them to certain religiosity or social group. So, the actual self-congruity in the social group is the influential variable to social capital. Hence, hypothesis four (H4) is that ASC is positively related to ER.

Islam et al. (2019) indicated that the ideal self-congruity is negatively related to symbolic incongruence. It is to say that ideal self-congruity was related to symbolic congruence. Intrinsic religiosity and spirituality are some kinds of symbolic representation and cognitive dimensions of social capital. Hence, Hypothesis five (H5) is that ISC is positively associated with IR. Hypothesis six (H6) is that ISC is positively associated with Spi.

According to Sarmiento et al. (2018), eWOM communication presents an essential information source 
for online users. Numerous researches have shown that other users' content is more credible and influential than the brand's content. Their finding confirmed that the quality of the relationship impacted eWOM communication. Besides, trust was a significant factor of eWOM communication because users want to look for a reliable source. Trust creates and maintains exchange relationships, leading to sharing knowledge of good quality (Blau, 1964). Hence, hypothesis seven (H7) is that Tru is positively related to online shared knowledge (OSK).

Davenport and Prusak (1998) indicated that reciprocity is one factor in driving knowledge sharing in the idea of the knowledge market. Wasko and Faraj (2005) noted that a high level of reciprocity facilitates the knowledge-sharing practice in electronic networks. Hence, hypothesis eight (H8) is that Rec is positively related to OSK.

Nahapiet and Ghoshal (1998) indicated that identification acts are a resource to influence motivation and then combine and exchange knowledge. Bergami \& Bagozzi (2000) noted that emotional identification raised loyalty and citizenship behaviors at the group level. It is also helpful in explaining individuals' willingness to maintain committed relationships with the members of virtual communities (Bagozzi \& Dholakia, 2002).

In contrast, the group members with distinct and contradictory identities would constitute significant barriers to information sharing, knowledge learning, and knowledge creation (Nahapiet \& Ghoshal, 1998). The virtual community exists in the mind of their members of the informal entities. In the group, the coherent members connect with other members. The members have shared specific problems and exciting things (Ardichvili et al., 2003). Hence, hypothesis nine (H9) is that Ide is positively related to OSK.

Nasse (2021) indicated that personality traits: age, gender would affect the relationship between extrinsic religiosity and consumer behaviors. The young consumers don't consider the religious prohibition of drinking non-halal drinks. Young consumers will consume both halal beverages and non-halal beverages. The young consumers with extrinsic religiosity have specific consumer behaviors.

According to Jamali and Sdiani (2013), the researchers investigated those 149 Lebanese managers from different firms of various sizes and industries. The research declaimed that extrinsic religiosity was positively related to a broader perspective of corporate social responsibility. Hence, hypothesis ten (H10) is that ER is positively associated with OSK.

According to Longenecker et al. (2004) and Vitell et al. (2005), intrinsic religiosity is related to higher 
ethical behavior. Higher intrinsic religiosity is associated with higher social desirability. The online shared knowledge is the social desirability behavior. Hence, hypothesis eleven (H11) is that IR is positively related to OSK.

Tan and Tan (2016) indicated that Confucian spirituality and Dao represent a shared vision of human excellence. The spiritual practitioners achieved Dao through harmony, where people find inner peace and co-exist with one another. So, the online practitioners with spirituality would share knowledge. Hence, hypothesis twelve (H12) is that Spi is positively related to OSK.

\section{METHODS}

\subsection{Measurement instruments and questionnaire development}

The intrinsic religiosity, extrinsic religiosity, and spirituality are the scales with five-four-four items (Allport \& Ross, 1967; Arli et al., 2016; Sardana et al., 2018; Vitell, 2009). According to Wang et al. (2015), the self-congruity scale has two constructs: actual self-congruity and ideal self-congruity. The actual self-congruity scale was for assessing believers' actual self-image congruity with spiritual brands. The ideal self-congruity scale was for assessing believers' ideal self-image congruity with spiritual brands. According to Youn and Jin (2017) and Sarmiento et al. (2018), the trust scale has three items. The scale of the norm of reciprocity has two items (Wasko \& Faraj, 2005; Chiu et al., 2006). The identification scale has four items (Bagozzi \& Dholakia, 2002; Chiu et al., 2006; Grootaert et al., 2004; Nahapiet \& Ghoshal, 1998). The scale of online shared knowledge has three items (Chiu et al., 2006; Nahapiet \& Ghoshal, 1998; Tsai \& Ghoshal, 1998) (see Appendix).

The questionnaire has these scales: actual self-congruity, ideal self-congruity, trust, the norm of reciprocity, identification, extrinsic religiosity, intrinsic religiosity, spirituality, online shared knowledge, and demographic variables. All items of scales translate into Chinese with a seven-point Likert scale anchored from '1 strongly disagree' to '7 strongly agree'.

The data were analyzed with Smart PLS (version 2.0). Significance levels were calculable by bootstrapping 250 samples 500 times. The convergent validity examines the model by factors loading, Cronbach's $\alpha$, composite reliability (CR), and average variation extracted (AVE). The questionnaire items were presented to scholars to boost content and face validity. A pretest was conducted with online practitioners from online websites. Based on the feedback or line group from fifty samples, the first version of the form did not change.

\subsection{Data collection and demographic profiles}

The interviewees participated in the online survey. The survey thoroughly clarified the purpose and 
objectives of the research. There were 119 questionnaires collected from interviewees, and all cases were valid. A total of 119 respondents are 82 (68.9\%) females and 37 (31.1\%) males. The majority age range is 20-29 years old ( 2 cases, $1.7 \%$ ), followed by 30-39 years old ( 5 cases, 4.2\%), 40-49 years old (27 cases, 22.7\%), 50-59 years old (56 cases, 47.1\%), and over 59 years old (29 cases, $24.4 \%)$. The education level of the participants includes junior or senior high school graduates (26.9\%, 32 cases), undergraduate degree (52.9\%, 63 cases) and graduate degree and over $(20.2 \%, 24$ cases). The participated time of spiritual or religious online group including not over twelve months $(8.4 \%$, 10 cases), one year to three years $(17.6 \%, 21$ cases $)$, more than three years to five years $(32.8 \%, 39$ cases), over five years to 10 years $(29.4 \%, 35$ cases $)$, and more than ten years $(11.8 \%, 14$ cases)

\subsection{Data analysis}

The researcher used partial least squares (PLS) regression and confirmatory factor analysis (CFA) to investigate the data. PLS software assessed the proposed theoretical framework, gauged the hypothesized intricate relationships among research constructs and checked the model. Later on, the bootstrapping method utilized the mediating role of variables inside the research framework.

\section{RESULTS}

\subsection{The measurement model}

The Cronbach's $\alpha$ and the CR of all constructs are more than 0.8 (see Table 1). The internal consistency between the constructs is high. Additionally, the factor loading of the constructed item is more significant than 0.8 ; therefore, the AVE of every construct is also bigger than 0.7 (see Table 1). The measurement has an excellent convergent effect.

\begin{tabular}{|c|c|c|c|c|c|}
\hline Construct & Item & Factor Loading & $\begin{array}{c}\text { Cronbach's } \\
\alpha\end{array}$ & $C R$ & AVE \\
\hline \multirow{3}{*}{ ASC } & ASC 1 & 0.877 & \multirow{3}{*}{0.919} & \multirow{3}{*}{0.948} & \multirow{3}{*}{0.860} \\
\hline & ASC 2 & 0.960 & & & \\
\hline & $\mathrm{ASC} 3$ & 0.943 & & & \\
\hline \multirow{3}{*}{ ISC } & $\operatorname{ISC} 1$ & 0.852 & \multirow{3}{*}{0.801} & \multirow{3}{*}{0.876} & \multirow{3}{*}{0.702} \\
\hline & ISC 2 & 0.828 & & & \\
\hline & ISC 3 & 0.834 & & & \\
\hline \multirow{2}{*}{ Tru } & Tru 1 & 0.955 & \multirow{2}{*}{0.957} & \multirow{2}{*}{0.972} & \multirow{2}{*}{0.920} \\
\hline & Tru 2 & 0.960 & & & \\
\hline
\end{tabular}




\begin{tabular}{|c|c|c|c|c|c|}
\hline & Tru 3 & 0.963 & & & \\
\hline \multirow{2}{*}{$\operatorname{Rec}$} & $\operatorname{Rec} 1$ & 0.949 & \multirow{2}{*}{0.912} & \multirow{2}{*}{0.957} & \multirow{2}{*}{0.918} \\
\hline & $\operatorname{Rec} 2$ & 0.968 & & & \\
\hline \multirow{4}{*}{ Ide } & Ide 1 & 0.942 & \multirow{4}{*}{0.947} & \multirow{4}{*}{0.962} & \multirow{4}{*}{0.864} \\
\hline & Ide 2 & 0.872 & & & \\
\hline & Ide 3 & 0.963 & & & \\
\hline & Ide 4 & 0.937 & & & \\
\hline \multirow{4}{*}{ ER } & ER 1 & 0.970 & \multirow{4}{*}{0.964} & \multirow{4}{*}{0.973} & \multirow{4}{*}{0.902} \\
\hline & ER 2 & 0.963 & & & \\
\hline & ER 3 & 0.924 & & & \\
\hline & ER 4 & 0.940 & & & \\
\hline \multirow{5}{*}{ IR } & IR 1 & 0.859 & \multirow{5}{*}{0.943} & \multirow{5}{*}{0.957} & \multirow{5}{*}{0.816} \\
\hline & IR 2 & 0.953 & & & \\
\hline & IR 3 & 0.942 & & & \\
\hline & IR 4 & 0.902 & & & \\
\hline & IR 5 & 0.855 & & & \\
\hline \multirow{4}{*}{ Spi } & Spi 1 & 0.929 & \multirow{4}{*}{0.944} & \multirow{4}{*}{0.958} & \multirow{4}{*}{0.850} \\
\hline & Spi 2 & 0.940 & & & \\
\hline & Spi 3 & 0.935 & & & \\
\hline & Spi 4 & 0.884 & & & \\
\hline \multirow{3}{*}{ OSK } & $\overline{\text { OSK } 1}$ & 0.932 & \multirow{3}{*}{0.933} & \multirow{3}{*}{0.957} & \multirow{3}{*}{0.881} \\
\hline & OSK 2 & 0.953 & & & \\
\hline & OSK 3 & 0.931 & & & \\
\hline
\end{tabular}

The analysis result shows that this study's nine constructs have high discriminate validity (see Table 2). All the values of square roots of AVE are higher than the values of the correlation coefficient of the constructs. 


\begin{tabular}{|c|c|c|c|c|c|c|c|c|c|}
\hline \multicolumn{10}{|c|}{ Table 2. Simple Correlation Matrix and Discriminant Validity } \\
\hline Construct & ASC & ISC & Tru & Rec & Ide & ER & IR & Spi & OSK \\
\hline ASC & 0.927 & & & & & & & & \\
\hline ISC & 0.791 & 0.838 & & & & & & & \\
\hline Tru & 0.533 & 0.420 & 0.959 & & & & & & \\
\hline Rec & 0.627 & 0.446 & 0.728 & 0.958 & & & & & \\
\hline Ide & 0.716 & 0.489 & 0.705 & 0.868 & 0.929 & & & & \\
\hline ER & 0.663 & 0.456 & 0.568 & 0.745 & 0.805 & 0.950 & & & \\
\hline IR & 0.505 & 0.612 & 0.203 & 0.249 & 0.244 & 0.291 & 0.903 & & \\
\hline Spi & 0.405 & 0.641 & 0.046 & 0.036 & 0.017 & 0.014 & 0.695 & 0.922 & \\
\hline OSK & 0.897 & 0.742 & 0.487 & 0.616 & 0.701 & 0.644 & 0.451 & 0.396 & 0.939 \\
\hline
\end{tabular}

\subsection{The structural model}

ASC is related to Tru, and the interpretation of variation (R2) is reaching 0.284. ASC is associated with Rec, and R2 is reaching 0.393. ASC is related to Ide, and R2 is reaching 0.513. ASC is associated with ER, and R2 is reaching 0.439. ISC is associated with IR, and R2 is running 0.375. ISC is related to Spi, and R2 is reaching 0.411. Ide, ER, and Spi are related to OSK, and R2 reaches 0.658 (see Figure 2).

Figure 2. Structural model PLS results

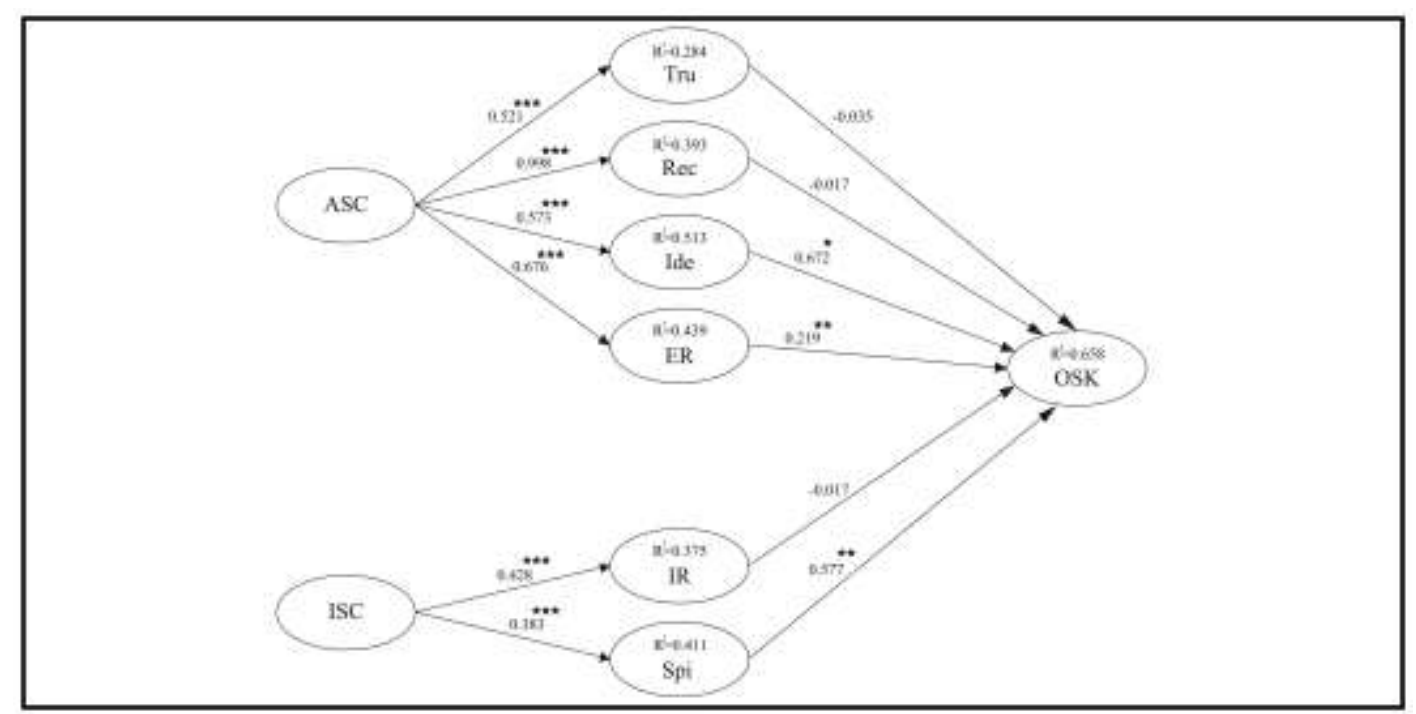




\section{International Journal of Research in Commerce and Management Studies}

ISSN 2582-2292

Vol. 3, No. 06 Nov-Dec; 2021 Page. No. 01-28

The results of the twelve research hypotheses show that nine are supported, and three are not supported. All of the research hypotheses validated the results displayed below (see Table 3 ).

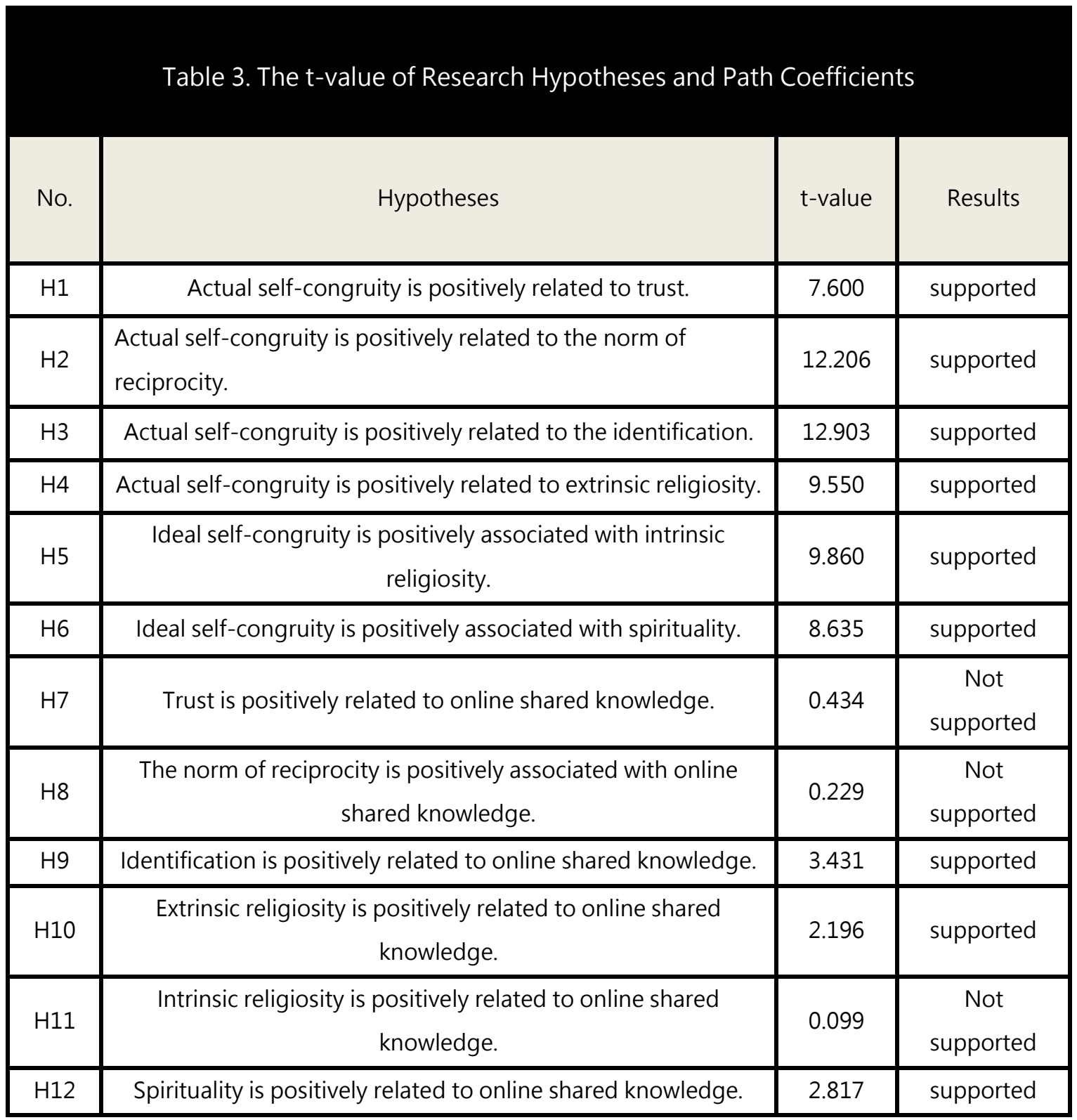

\section{DISCUSSION AND CONCLUSION}

\subsection{Discussion}

According to the proposed model, the variables of Self-congruity and social capital have an interactive 
relationship. Firstly, actual self-congruity has an interactive relationship with relational and structural dimensions of social capital. So, actual self-congruity is related to the variables of relational and structural dimensions of social capital: trust, the norm of reciprocity, identification, and extrinsic religiosity. Secondly, ideal self-congruity has an interactive relationship with the cognitive dimension of social capital. So, ideal self-congruity is related to intrinsic religiosity and spirituality.

According to self-congruity theory (Sirgy, 1986), people purchase goods and services to match the product's image consistent with their self-image. Individual behavior is dependent on the product's vision and the consumer's self-concept. Sirgy et al. (1991) defined self-congruity as cognitive matching between product attributes and consumer self-concept. Actual and ideal self-congruity played a critical role in customer behavior research (Sirgy, 2018).

Hung and Li (2007) indicated that the relational dimension of social capital refers to the norms, obligations, and social identity that provide interactive motivations for social cohesion (Dholakia et al., 2004). The structural dimension of social capital refers to the agenda, rules, and network configuration that provide opportunities for social interaction to connect (McCombs, 1992). Actual self-congruity also will improve the interaction between products and consumers. So, actual selfcongruity is related to relational and structural dimensions of social capital. According to social capital theory, relational and structural dimensions are concerned with the actual social capital phenomenon. The relational and structural dimensions of social capital are the same as the property of actual selfcongruity. The cognitive dimension of social capital refers to the shared frame of reference that motivates purposive exchange (Nahapiet \& Ghoshal, 1998). It is concerned about the ideal dimension. So, ideal self-congruity is related to the cognitive dimension of social capital.

According to social capital theory, social capital's relational and structural dimensions are the infrastructure of interactive relations. In this research, the identification of relational dimension and extrinsic religiosity of structural dimension would impact online shared knowledge. The cognitive dimension of social capital is the basis of idea exchange. The spirituality of the cognitive dimension would impact online shared knowledge.

\subsection{Limitations and future research}

The present research included some weaknesses. First, this study used a survey research method and purposive sampling from the SNSs in Taiwan. The generalization of research findings has some limitations. Future research should use a random sample to pick the subjects in diverse geographical locations.

Second, this study investigated online religious and spiritual practitioners. However, this study does 
not include multidimensional items and maintains the fundamental data concerning believers' selfcongruity and social capital variables. Hence, the questionnaire form should comprise all the religious or spiritual dimensions to analyze the believers' shared knowledge behaviors better. Future studies should address the multidimensionality of variables and items. Moreover, additional research must look at the parasocial interaction of believers' online behaviors.

Third, the proposed model predicts the relationship of believers' religiosity, spirituality, self-congruity, social capital, and online shared knowledge. The research findings can be improved by integrating additional factors that are more critical. For example, some researchers have declared the necessity of mixing anticipated emotions, personal feelings, attainable guilt, or group pride to explain believers' online shared knowledge habits and effects. Future research might embrace such positive and negative anticipated impacts on the united theoretical framework. Additionally, different types of believers can be the research subjects to determine what kinds of online spiritual or religious knowledge are shared, which would be a stimulating extension of this research in future studies.

\subsection{Conclusion}

The spiritual celebrity-worship process and self-congruity still have to be explored in literature. This study provided many crucial additional arguments to the prevailing literature.

First, the primary focus of this research is to merge self-congruity and social capital theories into one comprehensive theoretical framework in an online website's context site. The variables of social capital are the mediator variables, while online shared knowledge is the dependent variable. Actual self-congruity and ideal self-congruity are the independent variables. Actual self-congruity is related to relational and structural dimensions of social capital: trust, the norm of reciprocity, identification, and extrinsic religiosity. Ideal self-congruity is associated with the cognitive dimension of social capital: intrinsic religiosity and spirituality.

Second, actual self-congruity is the unity between spiritual or religious vision and true self-image. It would impact trust, the norm of reciprocity, identification, and extrinsic religiosity. The harmony of actual self-image and believed ideas would make the interaction between group members. Ideal selfcongruity is the unity between the spiritual or religious vision and perfect self-image. It would impact intrinsic religiosity and spirituality. The harmony of ideal self-image and believed idea would make the general knowledge between group members.

On the other hand, ideal self-congruity does not impact relational and structural dimensions of social capital because the online practitioner does not have unity between believed knowledge and selfimage. The cognitive dimension of social capital: intrinsic religiosity and spirituality believe in God 
or the highest spirit, not the actual situation. Actual self-congruity does not impact the cognitive dimension of social capital because the online practitioner has no congruence between general knowledge and self-image. It is not concerned about the ideal situation. Relational and structural dimensions of social capital: trust, the norm of reciprocity, identification, and extrinsic religiosity are that believers identify each other in a group and believe in God and oneself. It is a secular-religious orientation.

Third, ideal self-congruity derives from self-identity. Actual self-congruity derives from selfconsistency. The holistic model could explain believers' self-congruity comes from online spiritual brands with self-identity and self-consistency. Intrinsic religiosity and spirituality are related to selfidentity. Trust, the norm of reciprocity, identification, and extrinsic religiosity is associated with selfconsistency. Self-identity and self-consistency are related to sharing knowledge online. Identification and extrinsic religiosity impact online shared knowledge. Spirituality also impacts online shared knowledge.

\section{REFERENCES}

Adler, P. S. \& Kwon, S. W. (2002). Social capital: Prospects for a new concept. The Academy of Management Review, 27(1), 17-40.

A'guila-Obra, A. R. D., Padilla-Mele'ndeza, A., \& Al-dweeri, R. M. O. O. (2013). The influence of electronic service quality on loyalty in postal services: The mediating role of satisfaction. Total Quality Management, 24(10), 1111-23.

Ahmed, J. (2015). You are what You consume. Munich Personal RePEc Archive, Online at https://mpra.ub.uni-muenchen.de/64806/

Akrout, H. \& Nagy, G. (2018). Trust and commitment within a virtual brand community: The mediating role of brand relationship quality. Information \& Management, 55, 939-55.

Allport, G. W. \& Ross, J. M. (1967). Personal religious orientation and prejudice. Journal of Personality and Social Psychology, 5(4), 432-43.

Andrews, D. (2002). Audience-specific online community design. Communications of the ACM, 45(4), 64-8.

Ardichvili, A., Cardozo, R. \& Ray, S. (2003). A theory of entrepreneurial opportunity identification and development. Journal of Business Venturing, 18(1), 105-23.

Arli, D., Cherrier, H., \&Tjiptono, F. (2016). God blesses those who wear Prada: Exploring the impact of religiousness on attitudes toward luxury among the youth of Indonesia. Market Intelligence \& Planning, 34(1), 61-79.

Azizi, S. \&Daei, Z. (2014). A model of factors' effects on brand identification: Evidence from Iran. Asian Academy of Management Journal, 19(2), 123-39. 
Bagozzi, R. P. \& Dholakia, U. M. (2002). Intentional social actions in virtual communities. Journal of Interactive Marketing, 16(2), 2-21.

Beck, C. (1986). Education for spirituality. Interchange, 17(2), 148-56.

Bergami, M. \& Bagozzi, R. P. (2000). Self-categorization, affective commitment, and group selfesteem as distinct aspects of social identity in the organization. British Journal of Social Psychology, 39, 555-77.

Biswas, S., Hussain, M., \& O'Donnell, K. (2009). Celebrity endorsement in advertisements and consumer perceptions: A cross-culture study. Journal of Global Marketing, 22(2), 121-37.

Blau, P. M. (1964). Exchange and power in social life. John Wiley and Sons.

Bourdieu, P. (1977). Outline of a theory of practice. Cambridge University Press.

Bourdieu, P. (1986). The form of capital. In J. G. Richardson (Ed.), Handbook of theory and research for the sociology of education (pp. 241-258). Greenwood.

Bukhari, S. N. Z.\& Isa, S. M. (2019). Islamic branding: insights from a conceptual perspective. Journal of Islamic Marketing, 11(6), 1743-60.

Burt, R. S. (1992). Structural holes: The social structure of competition. Harvard University Press.

Calzati, S. \&Simanowski, R. (2018). Self-narratives on social networks: Trans-platform stories and Facebook's metamorphosis into a postmodern semiautomated repository. Biography: An Interdisciplinary Quarterly, 41(1), 24-47.

Carrim, J. N. (2018). The mediating role of actual self-congruity on the relationship between religion and store loyalty: A case of Mauritius. Journal of Management and Marketing Review, 3(4), 17984.

Clark, W. H. (1958). The psychology of religion. Pastoral Psychology, 9, 49-55.

Chiu, C. M., Hsu, M. H., \& Wang, E. T.G. (2006). Understanding knowledge sharing in virtual communities: A integration of social capital and social cognitive theories. Decision Support Systems, 42, 1872-88.

Choi, S. M. \& Rifon, N. J. (2012). It is a match: The impact of congruence between celebrity image and consumer ideal self on endorsement effectiveness. Psychology and Marketing, 29(9), 63950 .

Cicourel, A. V. (1973). Cognitive sociology. Penguin Books.

Cocker, H. L. \& Cronin, J. (2017). Charismatic authority and the YouTuber: Unpacking the new cults of personality. Marketing Theory, 17(4) 455-72.

Coleman, J. S. (1988). Social capital in the creation of human capital. American Journal of Sociology, 94, S95-S120.

Coleman, J. S. (1990). Foundations of social theory. Belknap Press of Harvard University Press

Darvyri, P., Galanakis, M., Avgoustidis, A. G., Pateraki, N., Vasdekis, S., \& Darviri, C. (2014). The revised intrinsic/extrinsic religious orientation scale in a sample of Attica's inhabitants. Psychology, 5(13), 1557-67. 
Davenport, T. H. \& Prusak, L. (1998). Working Knowledge: How Organizations Manage What They Know. Harvard Business School Press.

Dholakia, U. M., Bagozzi, R. P., \& Pearo, L. K. (2004). A social influence model of consumer participation in network- and small-group-based virtual communities. International Journal of Research in Marketing, 21(3), 241-63.

Dunkel, C. S. \& Lavoie, J. C. (2005). Ego-identity and the processing of self-relevant information. Self and Identity, 4, 349-59.

Elkins, D., Hedstrom, L., Hughes, L., Leaf, J., \& Saunders, C. (1988). Toward a humanisticphenomenological spirituality: Definition, description, and measurement. Journal of Humanistic Psychology, 28, 5-18.

Ellemers, N., Kortekaas, P., \& Ouwerkerk, J. W. (1999). Self-categorization, commitment to the group, and group self-esteem as related but distinct aspects of social identity. European Journal of Social Psychology, 29(2-3), 371-89.

Gan, M. \& Chen, S. (2017). Being your actual or ideal self? What it means to feel authentic in a relationship. Personality and Social Psychology Bulletin, 43(4), 465-78. [is.p.

Gefen, D., Karahanna, E., Straub, D. W. (2003). Trust and TAM in online shopping: An integrated model. MIS Quarterly, 27(1), 51-90.

Granovetter, M. S. (1992). Problems of explanation in economic sociology. In N. Nohria \& R. Eccles (Eds.), Networks and organizations: Structure, form, and action. (pp. 25-56). Harvard Business School Press.

Hatherell, M. \& Welsh, a. (2017). Rebel with a cause: Ahok and charismatic leadership in Indonesia. Asian Studies Review, 41(2), 174-90.

Hennig-Thurau, T., Gwinner, K. P., Walsh, G., \&Gremler, D. D. (2004). Electronic word-of-mouth via consumer-opinion platforms: What motivates consumers to articulate themselves on the Internet? Journal of Interactive Marketing, 18(1), 38-52.

Hofstede, G. \& Bond, M. H. (1984). Hofstede's culture dimensions: An independent validation using Rokeach's value survey. Journal of Cross-Cultural Psychology, 15(4), 417-33.

Holdcroft, B. B. (2006). What is religiosity? Catholic Education: A Journal of Inquiry and Practice, 10(1), 89-103.

$\mathrm{Hu}$, M., Zhang, M., \& Wang, U. (2017). Why do audiences choose to keep watching on live video streaming platforms? An explanation of dual identification framework. Computers in Human Behavior, 75, 594-606.

Huang, C. C., Lin, T. C., \& Lin, K. j. (2009). Factors affecting pass-along email intentions (PAEIs): Integrating the social capital and social cognition theories. Electronic Commerce Research and Applications, 8, 160-9.

Huber, F., Vollhardt, K., Matthes, I.,\& Vogel, J. (2010). Brand misconduct: consequences on consumer-brand relationships. Journal of Business Research, 63(11), 1113-20. 
Hung, K. H. \& Li, S. Y. (2007). The influence of eWOM on virtual consumer communities: Social capital, consumer learning, and behavioral outcomes. Journal of Advertising Research, 47(4), 485-95. DOI: 10.2501/S002184990707050X

Islam, T., Attiq, S., Hameed, Z., Kaokhar, M. N., \& Sheikh, Z. (2019). The impact of self-congruity (symbolic and functional) on the brand hate: A study based on self-congruity theory. British Food Journal, 12(1), 71-88. DOI 10.1108/BFJ-03-2018-0206

Jacobs, J. (1965). The death and life of great American cities. Penguin Books.

Jamali, D. \& Sdiani, Y. (2013). Does religiosity determine affinities to CSR?. Journal of Management, Spirituality, \& Religion, 10(4), 309-23. DOI: 10.1080/14766086.2013.802251

Johnson, A. R., Matear, M., \& Thomson, M. (2011). A coal in the heart: Self-relevance as a post-exit predictor of consumer anti-brand actions. Journal of Consumer Research, 38, 108-25. https://www.doi: 10.1086/657924

Kang, J., Tang, L., \& Lee, J. Y. (2015). Self-congruity and functional congruity in brand loyalty. Journal of Hospitality \& Tourism Research, 39(1), 105-31.

Lazarus, R., \& Folkman, S. (1984). Stress, appraisal and coping. Springer.

Lewis, N. (1978). The New Roget's Thesaurus of the English in Dictionary Form. Putnam.

Longenecker, J. G., McKinney, J. A., \& Moore, C. W. (2004). Religious intensity, evangelical Christianity, and business ethics: An empirical study. Journal of Business Ethics, 55(4), 371-84.

Magdalena, M. (2019). Personal online identity-brandingor impression management. BuletinStiintific, 24(1), 67-75.

Maltby, J. (1999). The internal structure of a derived, revised, and amended measure of the religious orientation scale: The 'Age- Universal' I-E scale-12. Social Behavior and Personality, 27(4), 40712.

McCombs, M. (1992). Explorers and surveyors: Expanding strategies for agenda-setting research. Journalism Quarterly, 69(4), 813-24.

McCormick, D. W. (1994). Spirituality and management. Journal of Managerial Psychology,9(6), 58.

Nahapiet, J. \& Ghoshal, S. (1998). Social capital, intellectual capital, and the organizational advantage. The Academy of Management Review, 2, 242-66.

Nasse, T. B. (2021). How and why extrinsic religiosity fashions Muslim consumer behavior in a multifaith geography. American Journal of Marketing Research, 7(1), 1-9.

Nolan, K. P. \& Harold, C. M. (2010). Fit with what? The influence of multiple self-concept images on organizational attraction. Journal of Occupational and Organizational Psychology, 83, 64562.

Nonaka, I. (1994). A dynamic theory of organizational knowledge creation. Organization Sciences, 5(1), 14-37. 
Norman, A. T., \& Russell, C. A. (2006). The pass-along effect: Investigatingword-of-mouth effects on online survey procedures. Journal of Computer-Mediated Communication, 11(4), 1085-103.

Pargament, K. I. (1999). The psychology of religion and spirituality? Yes and no. The International Journal for the Psychology of Religion, 9(1), 3-16, https://www.doi: 10.1207/ s15327582ijpr0901_2

Pargament, K. I., Ensing, D. S., Falgout, K., Olsen, H., Reilly, B., Van Haitsma, K.,\&Warren, R. (1990). God help me: (I): Religious coping efforts as predictors of the outcomes to significant negative life events. American Journal of Community Psychology, 18(6), 793-824.

Putnam, R. D. (1995). Bowling alone: America's declining social capital. Journal of Democracy, 6, 65-78.

Reich, K. H., Oser, F. K., \& Scarlett, W. G. (1999). Spiritual and religious development: Transcendence and transformations of the self. In K. H. Reich, F. K. Oser, \& W. G. Scarlett (Eds.), Being human: The case of religion, Vol. 2. Psychological studies on spiritual and religious development (pp. 7-24). Pabst Scientific Publishers.

Rokeach, M. (1973). The Nature of Human Values. Free Press.

Sardana, D., Gupta, N., \& Sharma, P. (2018). Spirituality and religiosity at the junction of consumerism: Exploring consumer preference for spiritual brands. International Journal of Consumer Studies, 42, 724-35. https://www.doi: 10.1111/ijcs.12467

Sarmiento, J. R., de Esteban, J. \&Antonovica, A. (2018). Word-of-mouth communication as a consequence of relationship Quality in online environments. Palabra Clave, 21(4), 1075-106. DOI: $10.5294 /$ pacla.2018.21.4.6

Schneiders, S. M. (1989). Spirituality in the academy. Theological Studies, 50(4), 676-97.

Seehusen, J., Cordaro, F., Wildschut, T., Sedikides, C., Routledge, C.,Blackhart, G. C., \&Vingerhoets, A. J. J. M. (2013). Individual differencesin nostalgia proneness: The integrating role of the need to belong. Personality and Individual Differences, 55, 904-8.

Sherman, A. C.\& Simonton, S. (2001). Religious involvement among cancer patients: Associations with adjustment and quality of life. In T. G. Plante \& A. C. Sherman (Eds.), Faith and Health: Psychological Perspectives (pp. 167-94). Guilford.

Shih, H. P., Lai, K. H., \& Cheng, T. C. E. (2013). Informational and relational influences on electronic word of mouth: An empirical study of an online consumer discussion forum. International Journal of Electronic Commerce, 17(4), 137-65.

Sirgy, M. J. (1985). Using self-congruity and ideal congruity to predict purchase motivation. Journal of Business Research, 13, 195-206.

Sirgy, M. J. (1986). Self-congruity: toward a theory of personality and cybernetics. Praeger.

Sirgy, M. J. (2018). Self-congruity theory in consumer behavior: A little history. Journal of Global Scholars of Marketing Science, 28(2), 197-207. DOI: 10.1080/21639159.2018.1436981

Sirgy, M. J., Grewal, D., Mangleburg, T. F., Park, J., Chon, K. S., Claiborne, C. B., Johar, J. S., \& 
Berkman, H. (1997). Assessing the predictive validity of two methods of measuring self-image congruence. Journal of the Academy of Marketing Science, 25(3), 229-41.

Sirgy, M.J., Johar, J., Samli, A.C. and Claiborne, C.B. (1991). Self-congruity versus functional congruity: Predictors of consumer behavior. Journal of the Academy of Marketing Science, 19(4), 363-75.

Smith, B. (1998). Buyer-seller relationships: Similarity, relationship management, and quality. Psychology \& Marketing, 15(1), 76-92.

Stolz, J. \& Usunier, J. C. (2019). Religions as brands? Religion and spirituality in consumer society. Journal of Management, Spirituality \& Religion, 16(1), 6-31.https://www. DOI: 10.1080/14766086.2018.1445008

Sun, T., Youn, S., Wu, G., \& Kuntaraporn, M. (2006). Online word-of-mouth(or mouse): An exploration of its antecedents and consequences. Journal of Computer-Mediated Communication, 11(4), 1104-27.

Tan, C. \& Tan, L. (2016). A shared vision of human excellence: Confusion Spirituality and arts education. Pastoral Care in Education, 34(3), 156-66.

Thibaut, J. W. \& Kelly, H. H. (1959). The social psychology of groups. John Wiley \& Sons.

Trimble, D. E. (1997). The religious orientation scale: Review and meta-analysis of social desirability effects. Educational and Psychological Measurement, 57(6), 970-86.

Tsai, W. \& Ghoshal, S. (1998). Social capital and value creation: The role of intra firm networks. Academy of Management Journal, 41, 464-78.

Uzuno $\breve{g l u}$, E.\&Kip, S. M. (2014). Brand communication through digital influencers: Leveraging blogger engagement. International Journal of Information Management, 34, 592-602.

Vigolo, V. \&Ugolini, M. M. (2016). Does this fit my style? The role of self-congruity in young women's repurchase intention for intimate apparel. Journal of Fashion Marketing and Management, 20(4),417-434.

Vitell, S. J. (2009). The role of religiosity in business and consumer ethics: A review of the literature. Journal of Business Ethics, 90(S2), 155-67.

Vitell, S. J., Paolillo, J. \& Singh, J. (2005). Religiosity and consumer ethics. Journal of Business Ethics, 57(2), 175-81.

Wang, S. J., Hsu, C. P., Huang, H. C., \& Chen, C. L. (2015). How readers' perceived self-congruity and functional congruity affect bloggers' informational influence. Online Information Review, 39(4), 537-55.

Wasko, M. M. \& Faraj, S. (2005). Why should I share? Examining social capital and knowledge contribution in electronic network of practice. MIS Quarterly, 29(1), 35-57.

Youn, S. \& Jin, S. V. (2017). Reconnecting with the past in social media: The moderating role of social influence in nostalgia marketing on Pinterest. Journal of Consumer Behavior, 16, 565-76.

Zhang, Y.\& Hiltz, S. R. (2003). Factors that influence online relationship development in a knowledge 
sharing community. Proceeding of the Ninth American Conference on Information Systems, 410-7.

Appendix: Survey Items

\begin{tabular}{|c|c|c|}
\hline Variable & Items & Reference \\
\hline Actual Self-Congruity & $\begin{array}{l}\text { 1. Concerning our characters, my online } \\
\text { spiritual vision and I are very similar. } \\
\text { 2. I resemble the typical believers of my } \\
\text { online spiritual vision very much. } \\
\text { 3. I can quickly identify with my online } \\
\text { spiritual vision. }\end{array}$ & $\begin{array}{l}\text { Huber et al. } \\
\quad(2010) \text {; } \\
\text { Wang et al. } \\
\quad(2015)\end{array}$ \\
\hline Ideal Self-Congruity & $\begin{array}{l}\text { 1. My idea of who I am is very similar to } \\
\text { my online spiritual or religious vision. } \\
\text { 2. While participating in my online spiritual } \\
\text { community, I want to show the best of } \\
\text { me. } \\
\text { 3. My online spiritual vision reflects my } \\
\text { ideal self. }\end{array}$ & $\begin{array}{l}\text { Huber et al. } \\
\quad(2010) \text {; } \\
\text { Wang et al. } \\
\quad(2015)\end{array}$ \\
\hline Trust & $\begin{array}{l}\text { 1. The online spiritual or religious vision } \\
\text { that I look for gives me a trustworthy } \\
\text { impression. } \\
\text { 2. I have trust in the spiritual or religious } \\
\text { online messages that I look for it. } \\
\text { 3. The spiritual or religious online vision } \\
\text { that I look for gives me a feeling of trust. }\end{array}$ & $\begin{array}{l}\text { Sarmiento et al. } \\
\qquad(2018) \\
\text { Youn and Jin } \\
\text { (2017) }\end{array}$ \\
\hline Norm of reciprocity & $\begin{array}{l}\text { 1. I know that other members in the online } \\
\text { spiritual or religious community will help } \\
\text { me, so it's only fair to help other } \\
\text { members. } \\
\text { 2. I believe that members in the online } \\
\text { spiritual or religious community would } \\
\text { help me if I need it. }\end{array}$ & $\begin{array}{l}\text { Wasko \& Faraj } \\
\text { (2005) } \\
\text { Chiu et al. } \\
\text { (2006) }\end{array}$ \\
\hline
\end{tabular}




\begin{tabular}{|c|c|c|}
\hline Identification & $\begin{array}{l}\text { 1. I feel a sense of belonging towards my } \\
\text { online spiritual or religious community. } \\
\text { 2. I have the feeling of togetherness or } \\
\text { closeness in my online spiritual or } \\
\text { religious community. } \\
\text { 3. I have a strong positive feeling toward } \\
\text { my online spiritual or religious } \\
\text { community. } \\
\text { 4. I am proud to be a member of my online } \\
\text { spiritual or religious community. }\end{array}$ & $\begin{array}{c}\text { Bagozzi \& } \\
\text { Dholakia (2002) } \\
\text { Grootaert et al. } \\
\text { (2004) } \\
\text { Nahapiet \& } \\
\text { Ghoshal (1998) } \\
\text { Chiu et al. } \\
\text { (2006) }\end{array}$ \\
\hline Extrinsic religiosity & $\begin{array}{l}\text { 1. I go to an online spiritual or religious } \\
\text { community because it helps me to } \\
\text { make friends. } \\
\text { 2. I go to an online spiritual or religious } \\
\text { community because I enjoy interacting } \\
\text { with people there. } \\
\text { 3. I go to an online spiritual or religious } \\
\text { community because it helps me feel } \\
\text { socially secure and cared for by } \\
\text { sacred objects. } \\
\text { 4. I enjoy interacting with friends in an } \\
\text { online spiritual or religious community } \\
\text { more than my other friends. }\end{array}$ & $\begin{array}{l}\text { Sardana et al. } \\
\text { (2018), Arli et } \\
\text { al. (2016), } \\
\text { Darvyri et al. } \\
\text { (2014), Maltby } \\
\text { (1999), Allport } \\
\text { and Ross(1967), } \\
\text { Vitell (2009) }\end{array}$ \\
\hline Intrinsic religiosity & $\begin{array}{l}\text { 1. I often hear religious sermons, talks, or } \\
\text { prayers in churches, temples, or other } \\
\text { sacred places. } \\
\text { 2. I live life according to my religious beliefs } \\
\text { and follow rituals. } \\
\text { 3. I often go to a religious place } \\
\text { 4. What religion offers me the most is } \\
\text { comfort in times of trouble and sorrow? } \\
\text { 5. I enjoy reading books about my faith. }\end{array}$ & $\begin{array}{l}\text { Sardana et al. } \\
\text { (2018), Arli et } \\
\text { al. (2016), } \\
\text { Darvyri et al. } \\
\text { (2014), Maltby } \\
\text { (1999), Allport } \\
\text { and Ross(1967), } \\
\text { Vitell (2009) }\end{array}$ \\
\hline Spirituality & $\begin{array}{l}\text { 1. I believe there is a connection between } \\
\text { all things that I cannot see but can sense. } \\
\text { 2. I believe in a Higher Power/Universal } \\
\text { Intelligence. } \\
\text { 3. I meditate to gain access to my inner } \\
\text { spirit. } \\
\text { 4. I have a relationship with a Higher } \\
\text { Power/Universal Intelligence. }\end{array}$ & $\begin{array}{l}\text { Sardana et al. } \\
\text { (2018), Arli et } \\
\text { al. (2016), } \\
\text { Darvyri et al. } \\
\text { (2014), Maltby } \\
\text { (1999), Allport } \\
\text { and Ross(1967), } \\
\text { Vitell (2009) }\end{array}$ \\
\hline
\end{tabular}




\begin{tabular}{l|l|l}
\hline \hline & $1 . \begin{array}{l}\text { Members in my online spiritual or } \\
\text { religious community share the vision of } \\
\text { helping others solve their problems. }\end{array}$ & $\begin{array}{c}\text { Nahapiet \& } \\
\text { Ghoshal (1998) } \\
\text { Tsai \& Ghoshal } \\
\text { Online Shared knowledge }\end{array}$ \\
2. $\begin{array}{l}\text { Members in my online spiritual or } \\
\text { religious community share the same goal } \\
\text { of learning from each other. }\end{array}$ & $\begin{array}{c}\text { (1998) } \\
\text { Chiu et al. } \\
\text { religious community share the same } \\
\text { value that helping others is pleasant. }\end{array}$ & \\
\hline \hline
\end{tabular}

